\title{
Retraction Note: The prospect of development of robotics in Russia
}

Ekaterina Nezhnikova and Khamzet Pshinshev

Peoples Friendship University of Russia (RUDN University), 6, Miklukho - Maklaya Str., Moscow, 117198, Russia

Published online: 29 June 2020

Withdrawn article: E3S Web of Conferences 175, 05043 (2020)

https://doi.org/10.1051/e3sconf/202017505043

The author Khamzet Pshinshev requested to withdraw this article because he confesses that he has copied some information without reference to them and without being authorized to do so. He reports that the Editors of the conference, his co-author Ekaterina Nezhnikova and the Publisher have no responsibility in this misconduct. 